\title{
Lymphoglandular Complexes in Proximal Colon of Buffalo Calves (Bubalus bubalis)
}

\author{
Complejos Linfoglandulares en Colon Proximal de Terneros de Buffalo (Bubalus bubalis)
}

Kritima Kapoor $^{*} \&$ Opinder Singh**

KAPOOR, K. \& SINGH, O. Lymphoglandular complexes in proximal colon of buffalo calves (Bubalus bubalis). Int. J. Morphol., 34(3):1137-1141, 2016.

SUMMARY: The present study was conducted on six healthy early neonatal and six prepubertal buffalo calves to study the location, gross morphology, histomorphology and histochemistry of lymphoglandular complexes in proximal colon. In very proximal part of colon of buffalo calves, an irregular oval mucosal lymphoid patch was found grossly as a proximal colon (PC) patch. Histologically, in proximal colon patch of early neonates (3-4 weeks), an extensive invasion of mucosal glands was observed towards lymphoid nodules that were present in submucosa. The structure as a whole thus formed a complex known as lymphoglandular complex (LGC). Large number of such complexes i.e., LGCs were observed in submucosa of proximal colon at this age. At some places, invasion of mucosal glands into lymphoid tissue was restricted to superficial layer of complexes, with the lymphoglandular complexes opening directly into the lumen but some were deep seated. However, by the age of 6 months in buffalo calves i.e., prepubertal period, LGCs were reduced and were present in single layer within the submucosa of the proximal colon. Moreover, some of LGCs were completely encapsulated by their own lamina muscularis mucosae. But some of the complexes still had their mucosal openings into lumen while others had lost their connection with tunica mucosa. Histochemically, the glands that were observed within LGCs contained mucosubstances, glycogen, mucopolysaccharides, and mucin. However, lipids were present around the lymphocytes observed towards the periphery of these LGCs.

KEY WORDS: Proximal colon; Lymphoglandular complex; Histomorphology; Histochemistry; Buffalo calves.

\section{INTRODUCTION}

The immune system is important for protection of body from several harmful exogenous and endogenous substances. So body has developed various primary and secondary lymphoid organs for generation of immune response. Mucosal lymphoid tissue, as a part of secondary lymphoid tissue, especially the gut associated lymphoid tissue (GALT), however, acts to prevent the pathogens to gain access to the surface epithelium and penetrate the underlying tissues. Gut, therefore, acts as first line of defense towards antigens entering through oral route. Lymphoid tissue aggregates in small intestine i.e., Peyer's patches functions to generate immune response against foreign antigens. Peyer's patches has been extensively studied in sheep, cattle, pigs, rodents and man (Cornes, 1965; Faulk et al., 1970; Sobhon, 1971; Owen \& Jones, 1974; Chu et al., 1979; Sminia et al., 1983; Reynolds \& Morris, 1983; Liebler, 1985), but lymphoid aggregates in submucosa of large intestine that formed lymphoglandular complexes (LGCs) received much less attention. Although a few workers have worked on lymphoid aggregates in colon of man (Kealy, 1976), rats (Crouse et al., 1989), dogs (Atkins \& Schofield, 1972) and pigs (Liebler et al., 1988) but work in the literature is deficient on lymphoglandular complexes in bovines, especially buffalo calves. Therefore, the present study was carried out with the aim to study the location, gross appearance, histomorphology and histochemistry of LGCs in proximal colon of buffalo calves.

\section{MATERIAL AND METHOD}

The present study was conducted on healthy six early neonatal and six prepubertal buffalo calves. The proximal colon tissues from large intestines were collected and processed for paraffin and frozen sectioning techniques. The sections were stained with Mayer's haematoxylin and eosin stain for histomorphological studies (Luna, 1968), Masson's

* Ph.D. Scholar, Division of Veterinary Anatomy, Guru Angad Dev Veterinary and Animal Sciences University (GADVASU), Ludhiana, India.

** Prof., Division of Veterinary Anatomy, Guru Angad Dev Veterinary and Animal Sciences University (GADVASU), Ludhiana, India. 
Trichrome stain for collagen fibers (Luna), Gridley's stain for reticular fibres (Sheehan \& Hrapchak, 1973), Verhoeff's for elastic fibers (Sheehan \& Hrapchak), Alcian blue for mucosubstances ( $\mathrm{pH}$ 2.5), McManus' PAS method for glycogen, Mayer's mucicarmine method for mucin, and Sudan black B method for fats (Luna).

\section{RESULTS AND DISCUSSION}

In very proximal part of colon of 3-4 week old calves, an irregular oval elevated $(2.0 \pm 0.1 \mathrm{~cm}$ in length) mucosal lymphoid patch was found grossly as proximal colon (PC) patch. Several small openings distributed randomly over the irregular mucosal folds were present. By the age of 6 months, this proximal colon patch significantly increased in size into a large grossly evident oval patch $(3.5 \pm 0.1 \mathrm{~cm}$ in length) formed by several mucosal folds mixed with lymphoid tissue raised above mucosa. Small pores or openings, $15-20$ in number, located randomly over the irregular mucosal folds of patch were present (Fig. 1). These pores were the openings of lymphoglandular complexes (LGCs) that were formed within the patch and were confirmed histologically. Atkins \& Schofield and Abd-El-Hady et al. (2013) reported the similar observations in caecum and colon of adult dogs.

Histologically, in proximal colon patch of early neonates at the age of 3-4 weeks, an extensive invasion of mucosal glands of the crypt area was observed towards lymphoid nodules present in submucosa. The structure as a whole thus formed lymphoglandular complex, located on antimesenteric side of the intestinal wall (Fig. 2). Many other workers have also observed that the lymphoglandular complexes were present in the proximal colon and were

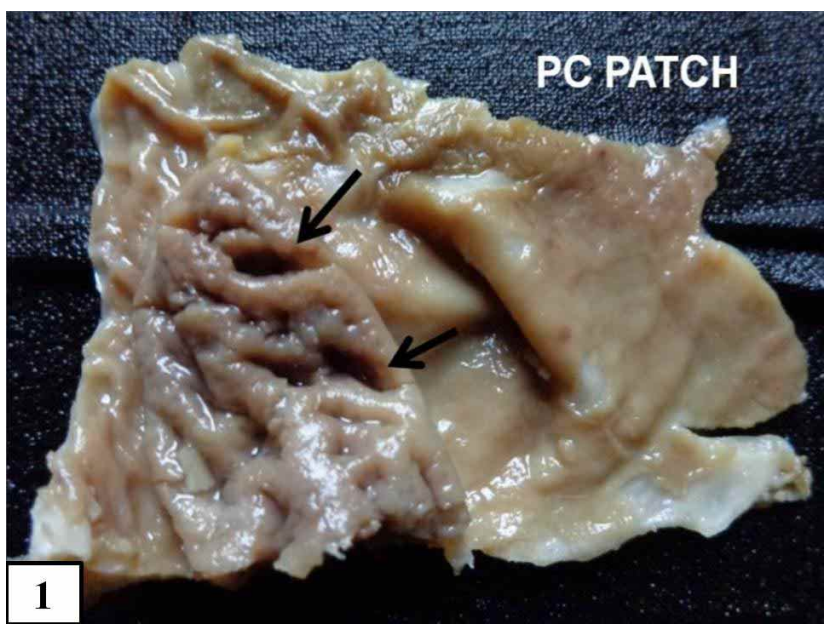

Fig. 1. Representative photograph showing gross location, appearance of proximal colon (PC) patch and mucosal openings (arrows) of lymphoglandular complexes in 6 month old buffalo calves.

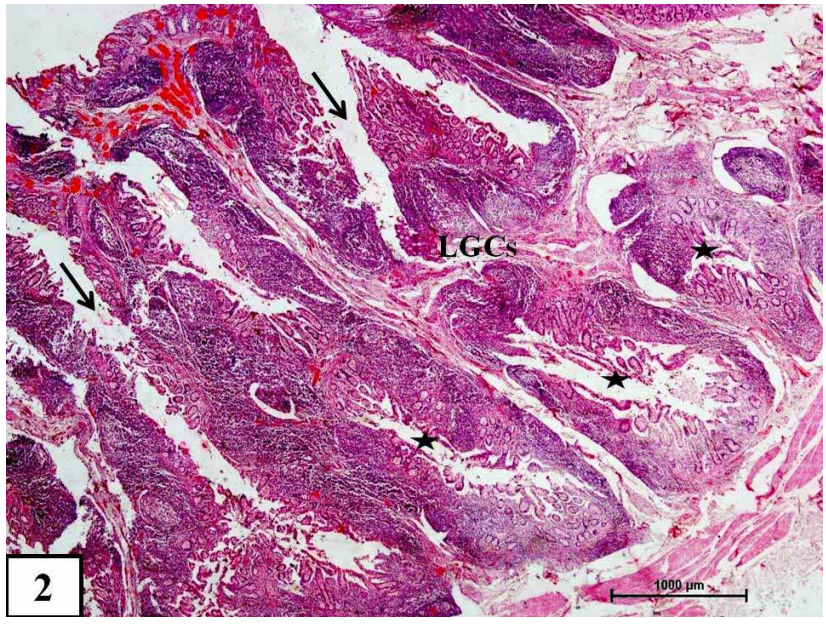

Fig. 2. Photomicrograph of proximal colon patch of 3-4 weeks buffalo calf showing number of lymphoglandular complexes (LGCs) with some of the complexes opening into lumen (arrows) while others having no connection with lumen (stars) (Haematoxylin and Eosin x 20).

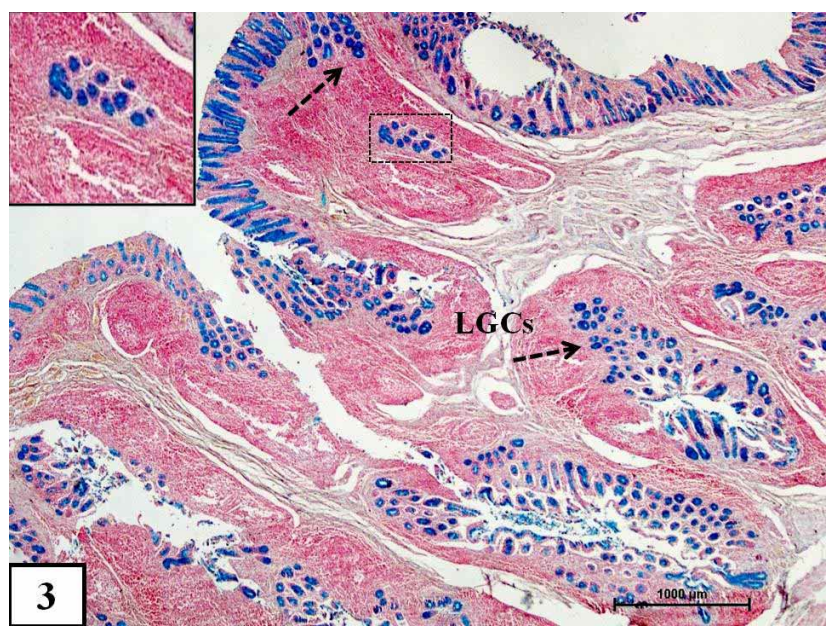

Fig. 3. Representative photograph of 3-4 weeks buffalo calf's proximal colon showing strong positive reaction for acid mucoplysaccharides in intestinal glands invading the lymphoid tissue (arrow), present within the lymphoid tissue (boxed; inset) in submucosa and within lymphoglandular complexes (LGCs) (dotted arrow) (Alcian Blue X 20).

oriented towards the antimesenteric border in mouse (Deasy et al., 1983) and porcine (Liebler et al.). There was disintegration of lamina muscularis mucosae where mucosal glands of the crypt region invaded the submucosal lymphoid tissue. This view was similar to that expressed in caecum and colon of adult dogs (Atkins \& Schofield; Abd-El-Hady et al.). At some places, invasion of mucosal glands into the lymphoid tissue was restricted to its superficial layer, with lymphoglandular complexes opening directly into the lumen. Some of the deeply seated LGCs also had openings into lumen while others had no connection (Fig. 2). Abundant 
collagen and reticular fibers were observed in between the lymphoid tissue and were encapsulating the lymphoglandular complexes. Similarly Liebler $\mathrm{et} \mathrm{al}$. reported in calves that in the lymphoglandular complexes, epithelial diverticulum extended from the intestinal lumen through muscularis mucosae, branched further into the lymphoid tissue and in the center an asymmetrically shaped transverse fold of lymphoid tissue protruded from the bottom. Moreover, the openings of these LGCs opened on elevations formed by mucosal folds of proximal colon patch visible grossly (Fig. 1). This was in accordance with the observations of Atkins

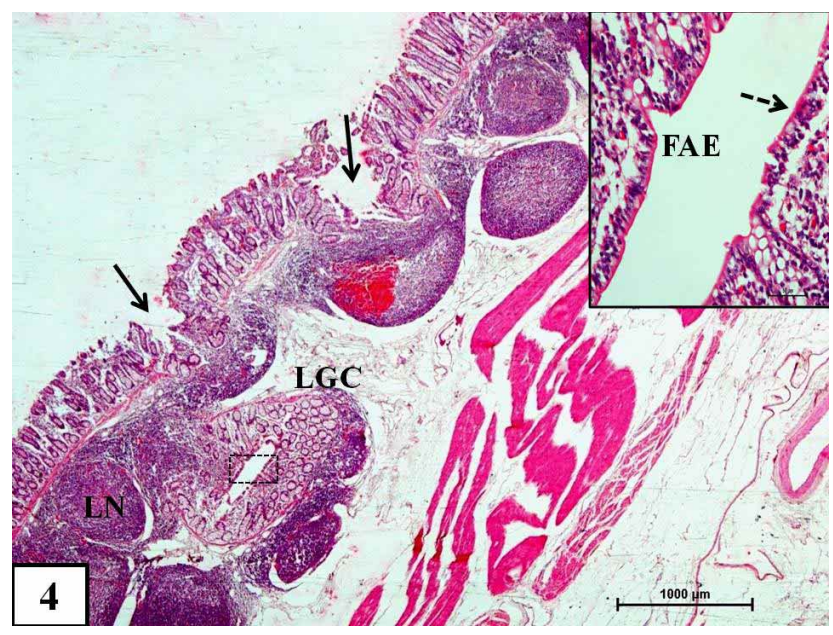

Fig. 4. Photomicrograph of proximal colon in 6 month old buffalo calf showing lymphoglandular complex (LGC) with their mucosal openings (arrows), various lymphoid nodules (LN) in submucosa (Haematoxylin and Eosin x 20). [Boxed: Inset showing follicle associated epithelium (FAE) lined by columnar cells having lymphocytes (arrow)] (Haematoxylin and Eosin x 400).

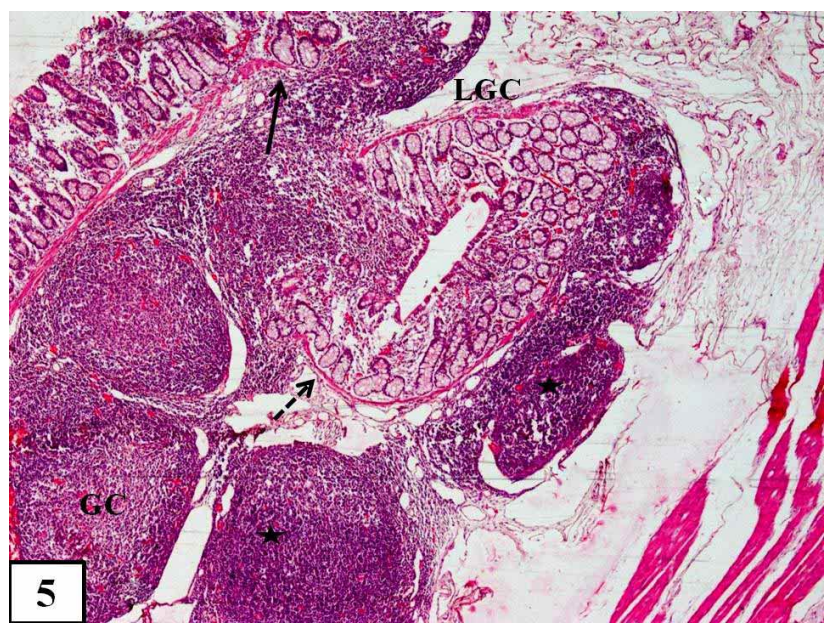

Fig. 5. Photomicrograph showing mucosal glands entering lymphoid tissue of proximal colon of 6 month old buffalo calf by disintegration of lamina muscularis mucosae, lymphoid nodules with germinal center (GC), without GC (stars), lymphoglandular complex (LGC) also without GC and is enclosed by its own lamina muscularis mucosae (dotted arrow) (Haematoxylin and Eosin X40).
\& Schofield in dogs. Moreover, at some locations the lymphoid nodules without association with the glandular epithelium was also present.

However, by the age of 6 months, in buffalo calves LGCs were reduced to be present in single layer in proximal colon. Some of the complexes still had their mucosal openings into the lumen while others had lost their connection with tunica mucosa (Fig. 4). Moreover, some of LGCs were completely encapsulated by their own lamina muscularis mucosae (Fig. 5). The center of the LGC presented overlying mucous membrane that formed an irre-

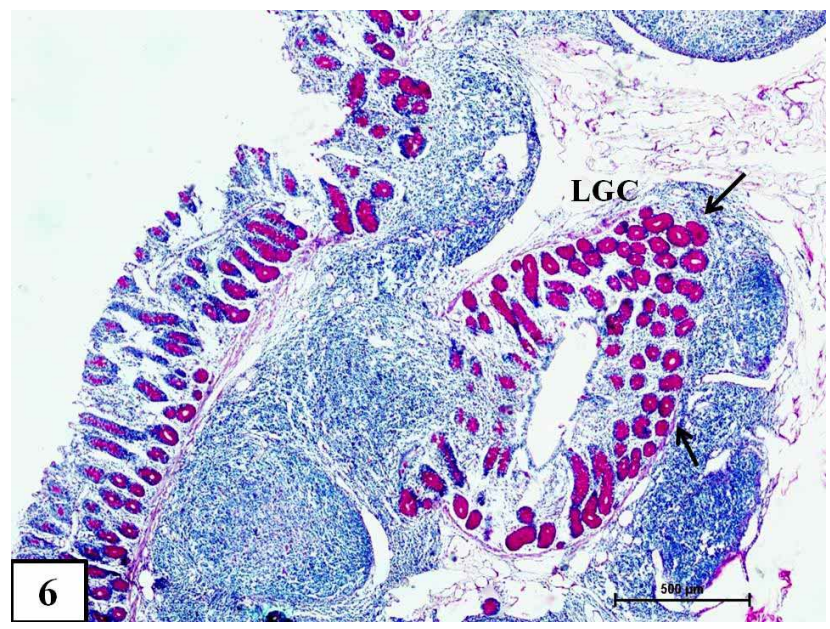

Fig. 6. Photomicrograph of proximal colon in 6 month old buffalo calf showing very strong PAS positive substance in mucosal glands entering lymphoglandular complex (LGC) and in glands just above the lymphoid tissue (arrows) i.e., away from the center of LGC (McManus' Method x 40).

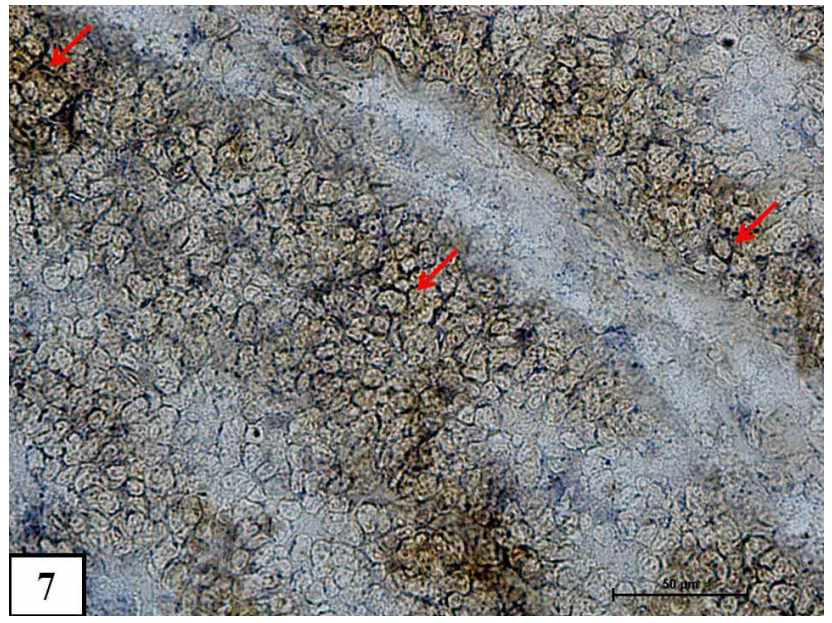

Fig. 7. Photomicrograph of proximal colon in 6 month old buffalo calf showing small amount of phospholipids, distributed especially around the peripheral cytoplasmic rims of lymphocytes (red arrows) located at the periphery of Lymphoglandular complex (LGC). Acid Haematin X400. 
gular oval depression, pit or disc like structure. This was lined by a specialized epithelium known as follicle associated epithelium (FAE). Its FAE in center had columnar cells with lymphocytes present within them (Fig. 5). Goblet cells were scanty in this lining epithelium. The epithelium however, contained mixed M-cells with lymphocytes within them, distributed among the enterocytes. Moreover, similar observations were made in proximal colon of rat (Bland \& Britton, 1984), in pigs (Liebler et al.) and in mice (Owen et al., 1991). Some submucosal lymphoid nodules present were found to be uniform, with very few having division into dark and light zones i.e., germinal center formation whereas the submucosal LGCs lacked the germinal center (Fig. 5). Similar findings were made by Abd-El-Hady et al. in caecum of mongrel dogs. Germinal center formation however could have been resulted from antigen exposure to the animal. This fact is confirmed by Owen et al. in mice and Mansfield \& Gauthier (2004) in colonic LGCs of swine.

Histochemically, the glands that were already present within the lymphoid tissue in proximal colon patch were uniform strong positive (+++) for acidic mucopolysaccharides whereas center of the lymphoid tissue showed weak to negligible alcinophilic reaction (+/-) (Fig. $3)$. Strong PAS positive $(+++)$ reaction in the glands confirmed the presence of neutral mucopolysaccharides content also in the glands that were associated with the lymphoglandular complexes. Especially the glands just above the lymphoid tissue of LGCs i.e., those away from center of LGC were strongly PAS positive (+++) (Fig. 6). Similarly, O'Leary \& Sweeny (1987) reported in humans that mucin produced by LGC epithelium showed a gradual reduction in proportion of neutral and increase in proportion of acidic mucopolysaccharides. Glandular diverticulum into lymphoid tissue of proximal colon patch showed strong
$(+++)$ positive reaction for mucin by Mayer mucicarmine method. Lymphocytes in the periphery of LGCs contained small amount of lipids especially on their peripheral cytoplasmic rims and showed moderate reaction (++) with Sudan black-B. Similarly, the distribution of phospholipids was also observed around the cytoplasmic rims of lymphocytes located towards the periphery of LGCs when stained with Acid haematin (Fig. 7).

\section{CONCLUSIONS}

All the observations above, lead to the conclusion that the lymphoid tissue present in submucosa of proximal colon formed a complex with invasion of glandular mucosa into them, known as lymphoglandular complex. Several small openings were distributed randomly over the irregular mucosal folds of colonic patch. These pores were the openings of LGCs. The center of LGCs was lined by specialized FAE that was mainly involved in the antigen uptake and which further generate the immune response by lymphoid tissue of LGCs. The histochemical studies revealed that the mucosal glands within the LGCs contained mucosubstances, glycogen, mucopolysaccharides, and mucin. However, lipids were observed around the peripheral lymphocytes in the LGCs of buffalo calves.

\section{ACKNOWLEDGEMENTS}

The authors are thankful to Guru Angad Dev Veterinary and Animal Sciences University (GADVASU), Ludhiana for providing all type of facilities to carry out the study.

KAPOOR, K. \& SINGH, O. Complejos linfoglandulares en colon proximal de terneros buffalo (Bubalus bubalis) Int. J. Morphol., 34(3):1137-1141, 2016.

RESUMEN: El presente estudio se llevó a cabo en seis terneros de búfalo neonatos sanos y seis terneros prepuberales para estudiar la ubicación, morfología macroscópica, histomorfología e histoquímica de los complejos linfoglandulares en el colon proximal. Se observó en un área del colon proximal (AP) de los terneros de búfalo un óvalo linfoide de mucosa irregular en la parte más proximal de éste. Histológicamente, en el área proximal del colon de los terneros neonatos (3-4 semanas), se observó una invasión extensa de las glándulas mucosas hacia los nódulos linfáticos presentes en la submucosa. La estructura en su totalidad formaba un complejo conocido como complejo linfoglandular (CLG). A esta edad se observó un gran número de estos complejos es decir, se observaron CLGs en la submucosa del colon proximal. La invasión de las glándulas mucosas en el tejido linfoide, se limita a la capa superficial de los complejos, los complejos linfoglandulares distribuidos directamente en el lumen, sin embargo otros se encontraban arraigados de manera profunda. En búfalo a los 6 meses de edad, es decir en el período prepuberal, se observó un número reducido de CLGs presentes en una sola capa dentro de la submucosa del colon proximal. Por otra parte, algunos de CLGs estaban completamente encapsulados por su propia lamina muscularis mucosae. Algunos de los complejos mantenían abertura de las mucosas en el lumen, mientras que otros habían perdido su conexión con la mucosa. En análisis histoquímico, las glándulas que se observaron dentro del CLGs contenían mucosustancias, glucógeno, mucopolisacáridos y mucina. Sin embargo, se encontraron lípidos presentes alrededor de los linfocitos hacia la periferia de los CLGs.

PALABRAS CLAVE: Colon proximal; Complejo linfoglandular; Histomorfología; Histoquímica; Terneros búfalo. 


\section{REFERENCES}

Abd-El-Hady, A. A. A.; Misk, N. A.; Haridy, M. A. \& Zayed, M. N. Morphometric and histological studies of the cecum in Mongrel dogs. Life Sci. J., 10(4):3172-8, 2013.

Atkins, A. M. \& Schofield, G. C. Lymphoglandular complexes in the large intestine of the dog. J. Anat., 113(Pt. 2):169-78, 1972.

Bland, P. W. \& Britton, D. C. Morphological study of antigensampling structures in the rat large intestine. Infect. Immun., 43(2):693-9, 1984.

Chu, R. M.; Glock, R. D. \& Ross, R. F. Gut-associated lymphoid tissues of young swine with emphasis on dome epithelium of aggregated lymph nodules (Peyer's patches) of the small intestine. Am. J. Vet. Res., 40(12):1720-8, 1979.

Cornes, J. S. Number, size, and distribution of Peyer's patches in the human small intestine: Part I The development of Peyer's patches. Gut, 6(3):225-33, 1965.

Crouse, D. A.; Perry, G. A.; Murphy, B. O. \& Sharp, J. G. Characteristics of submucosal lymphoid tissue located in the proximal colon of the rat. J. Anat., 162:53-65, 1989.

Deasy, J. M.; Steele, G. Jr.; Ross, D. S.; Lahey, S. J.; Wilson, R. E. \& Madara, J. Gut-associated lymphoid tissue and dimethylhydrazine-induced colorectal carcinoma in the Wistar/Furth rat. J. Surg. Oncol., 24(1):36-40, 1983.

Faulk, W. P.; McCormick, J. N.; Goodman, J. R.; Yoffey, J. M. \& Fudenberg, H. H. Peyer's patches: morphologic studies. Cell Immunol., 1(5):500-20, 1970.

Kealy, W. F. Colonic lymphoid-glandular complex (microbursa): nature and morphology. J. Clin. Pathol., 29(3):241-4, 1976.

O’Leary, A. D. \& Sweeny, E. C. Lymphoglandular complexes of the normal colon: histochemistry and immunohistochemistry. Ir. J. Med. Sci., 156(5):142-8, 1987.

Liebler, E. M.; Pohlenz, F. \& Woode, G. N. Gut-associated lymphoid tissue in the large intestine of calves. I. Distribution and histology. Vet. Pathol., 25(6):503-5, 1988.

Liebler, E. Number, Distribution and Size of Solitary and Aggregated Lymphatic Follicles in the Small Intestine of Calves, with Reference to their Surface Structure. $\mathrm{PhD}$ Thesis. Hannover, Institut fur Pathologie de Tierarztlichen Hochschule, 1985.

Luna, L. G. Manual of Histologic Staining methods of the Armed Forces Institute of Pathology. $3^{\text {rd }}$ ed. New York, Blakiston Division, McGraw-Hill, 1968.
Mansfield, L. S. \& Gauthier, D. T. Lymphoglandular complexes are important colonic sites for immunoglobulin A induction against Campylobacter jejuni in a swine disease model. Comp. Med., 54(5):514-23, 2004.

Owen, R. L. \& Jones, A. L. Epithelial cell specialization within human Peyer's patches: an ultrastructural study of intestinal lymphoid follicles. Gastroenterology, 66(2):189-203, 1974.

Owen, R. L.; Piazza, A. J. \& Ermak, T. H. Ultrastructural and cytoarchitectural features of lymphoreticular organs in the colon and rectum of adult BALB/c mice. Am. J. Anat., 190(1):10-8, 1991.

Reynolds, J. D. \& Morris, B. The evolution and involution of Peyer's patches in fetal and postnatal sheep. Eur. J. Immunol., 13(8):627-35, 1983.

Sheehan, D. C. \& Hrapchak, B. B. Theory and Practice of Histotechnology. St. Louis, The CV Mosby Company, 1973. pp.79-115.

Sminia, T.; Janse, E. M. \& Plesch, B. E. Ontogeny of Peyer's patches of the rat. Anat. Rec., 207(2):309-16, 1983.

Sobhon, P. The light and the electron microscopic studies of Peyer's patches in non germ-free adult mice. J. Morphol., 135(4):457-81, 1971.

\author{
Correspondence to: \\ Kritima Kapoor Ph.D. \\ Scholar, Division of Veterinary Anatomy \\ Guru Angad Dev Veterinary and Animal Sciences \\ University (GADVASU) \\ Ludhiana- 141004 \\ Punjab \\ INDIA
}

Email: kritimakapoor89@gmail.com

Received: 01-10-2015

Accepted: 12-04-2016 